\title{
Narrative Desire and Textual Consummation in Haida, Tlingit, and Northern-Dene Textualized Orature: A Critical Review Essay on Narrative Revitalization
}

\author{
Jasmine Spencer
}

\begin{abstract}
Associated with the rubric of desire and consummation are four interrelated challenges for the critical interpretation of oral narratives transformed into printed texts: the boundaries of the discursive (presence and absence), the recursive (orality and literacy), the ontological (animality and humanity), and the metaphysical (reincarnation and rewriting) that occur in the collaborations I examine in this review article of oral-literary methodologies and ideologies. I focus on better-known and lesserknown key examples from Haida, Tlingit, and northern-Dene orature as culturally and linguistically defined bodies of oral literature that follow from two interconnections between them: the bioregional and the bibliographical. By comparing essentially Modern conditions for interpretive uncertainty with interpretive cues found in the stories themselves, through a critical review of the colonial and decolonial poetics of orature, I argue that cross-border ways of thinking with these stories may enact narrative revitalization (cf. Spencer, "Telling Animals"; "The Soundscape") through the circulation of meaning as "desire" and as "consummation."
\end{abstract}

Keywords: Indigenous languages and literatures; textualized orature; Indigenous epistemologies; decolonial semiotics; comparative poetics

Résumé : Lors de l'interprétation critique de narrations orales converties en textes écrits, quatre défis interconnectés associés aux sujets de désir et d'accomplissement apparaissent. II s'agit des limites discursives (présence et absence), du récursif (oralité et littéracie), de l'ontologique (animalité et humanité) et du métaphysique (réincarnation et réécriture) qui émergent dans les collaborations que j'étudie dans cet article de synthèse au sujet des idéologies et méthodologies littéraires-orales. Je m'intéresse plus particulièrement aux exemples connus et moins connus de l'orature haïda, tlingit et dénée du nord qui sont des ensembles culturels et linguistiques définis de la littérature orale et qui résultent de deux interconnections existantes entre eux : le biorégional et le bibliographique. En utilisant surtout la comparaison entre les conditions modernes (et post-modernes) de l'incertitude de l'interprétation ainsi que les indices interprétatifs trouvés dans les histoires, et en recourant à une analyse critique de la poétique décoloniale de l'orature, je soutiens qu'une pensée transfrontalière de ces histoires peut entrainer une revitalisation des récits (cf. Spencer "Telling Animals"; "The Soundscape") grâce à la circulation du sens qui devient « désir » et « accomplissement ».

Mots clés : langues et littératures Autochtones; orature textualisée; épistémologies Autochtones; sémiotique décoloniale; poétique comparative

Resumen: A la rúbrica del deseo y de la consumación se asocian cuatro desafíos interrelacionados para la interpretación crítica de las narraciones orales llevadas a textos impresos: las fronteras de lo discursivo (presencia y ausencia), lo recursivo (oralidad y alfabetización), lo ontológico (animalidad y humanidad), y lo metafísico (reencarnación y reescritura). Estos están presentes en las colaboraciones que analizo en este artículo acerca de las metodologías y las ideologías oral-literarias. El análisis se centra en ejemplos clave, algunos conocidos, otros menos, de la oratura haida, tlingit y dené del Norte vistos como entidades cultural y lingüísticamente definidas de la literatura oral que se derivan de dos interconexiones: la biorregional y la bibliográfica. A partir de una comparación entre condiciones fundamentalmente modernas (y postmodernas) en lo concerniente a la incertidumbre interpretativa y las pistas interpretativas que se encuentran en los relatos mismos, sostengo, a través de la revisión crítica de la poética descolonial de la oratura, que los modos de pensar en estos relatos pueden establecer una revitalización narrativa (cf. Spencer "Telling Animals"; "The Soundscape") mediante la circulación del significado como "deseo" y como "consumación".

Palabras clave: lenguas y literaturas Indígenas; oratura textualizada; epistemologías Indígenas; semiótica descolonial; poética comparativa 
Resumo: Associados à rubrica do desejo e consumação, há quatro desafios interrelacionados para a interpretação crítica de narrativas orais transformadas em textos impressos: os limites do discursivo (presença e ausência), do recursivo (oralidade e literacia), do ontológico (animalidade e humanidade) e do metafísico (reencarnação e reescrita), que ocorrem nas colaborações que examino nesta análise crítica das metodologias e ideologias oral-literárias. Focalizo os exemplos-chave mais e menos conhecidos da oratura de Haida, Tlingit e Dene do Norte como corpos definidos cultural e linguisticamente da literatura oral, que resultam de duas interconexões entre si: o biorregional e o bibliográfico. Comparando as condições essencialmente modernas (e pós modernas) para a incerteza interpretativa com as pistas para a interpretação encontradas nas próprias histórias, através de uma análise crítica da poética decolonial da oratura, argumento que formas transfronteiriças de pensar com essas histórias podem validar a revitalização narrativa (cf. Spencer "Telling Animals"; "The Soundscape") através da circulação do significado como "desejo" e como "consumação".

Palavras-chave: línguas e literaturas Indígenas, oratura textualizada, epistemologias Indígenas, semióticas decoloniais, poética comparativa

\section{Introduction}

In this article, I analyze Haida, Tlingit, and northern-Dene "textualized orature"—oral narratives that have been transformed into print in ethnographic texts (Gingell 286) predicated upon the following line of enquiry: Narrative desire, textual consummation? within the historical and theoretical framework of two disciplines (English literature and anthropology) and the resulting body of work (textualized orature). In doing so, I also turn to the stories themselves for cues to their interpretation, thus enacting my experience of the power of narrative revitalization-the revivifying process of allowing these stories to become part of oneself, and one's critical process, in an expression of what I might describe as ontological entextualization (cf. Spencer, "Telling Animals"; "The Soundscape"). My cultural focus follows from two interconnections between Haida, Tlingit, and northern-Dene collections: the bioregional and the bibliographical. In turn, the bioregional and bibliographical are phenomena defined by interpretive exchange, which I construe as desire and consummation. Associated with the rubric of desire and consummation are four interrelated challenges for the critical interpretation of oral narratives transformed into printed texts: the boundaries of the discursive (presence and absence), the recursive (orality and literacy), the ontological (animality and humanity), and the metaphysical (reincarnation and rewriting) that occur in the collaborations I examine below.

The cross-disciplinary, collaborative process of the production, transmission, and reception of textualized orature requires analysis at the "midway [point] between literary criticism, which focuses on works, and bibliography, which focuses on books as books" (Williams and Abbott 54). While, in literary studies, close readings of texts combine attention to form and content so that form illuminates the critic's understanding of content and content the critic's understanding of form, the ethnographic means of producing many of the oral narratives I analyze here, in combination with the mediation of these narratives into print, require that I treat the social context of the production of these narratives as part of the formal nature of the same: this is crucial to a critical review of the methods and ideologies of an ethnographically instituted textual tradition. 
The work of Franz Boas (1858-1942), the "founder" of American anthropology, was in part inspired by the discipline of philology, a discipline that has also, in part, given rise to literary studies; thus, these disciplines share both methodological roots (Boas; Harpham 71, 76) as well as a major Modern interpretive crux-intersubjectivity.

This intersubjective crux is especially apparent when analyzing textualized narratives constituted by multiple forms, media, languages, cultures, and disciplines. In combining texts with methods from the two disciplines of literary studies and anthropology, my intention is to assess the aesthetic and ethical dimensions of the production and reception of textualized orature in terms of the texts' own contexts and contents: a methodology and ideology which I owe to decolonial poetics-a movement which, at its most honest, investigates itself without dispensation-in this case, to interpret regeneratively translated collections of Indigenous narratives as produced through the mode of "entextualization", which is "not simply . . . the structural effects but . . . the process itself-the generation of textuality" (Briggs and Bauman 147). Colonial textuality dictates that there is nothing outside the text (with apologies to Jacques Derrida).

My decolonial approach in this article is meant to suggest that while the idea of a text exists and cannot be ignored, the world might not always be constituted only as the text, even when the text is already part of the world. This agnostic double-vision is true for me, at least, as a Euro-American wishing to learn more respectful ways of thinking and being without attempting (inevitably unsuccessfully) to dispense totally with the terms of my epistemological formation. While I do not owe readers an account of my positionality - of course, no one owes anyone an account of their identity-I do owe to the process of narrative semiosis the articulation of my cultural position! Margery Fee writes, "Nowhere in reality is there an escape from our unrelenting process of self-dispossession-not even for Native people" (29), which is true both in terms of colonial and decolonial work. To find a way out of the supremacy of text which colonial ontologies dictate, if not out of the primacy of text, for me, I will reverse textual interpretive structures, so that I can look at how to re-read colonial context using Indigenous content for the sake of engaging with always-already interculturally mediated texts. This is, of course, just one of many ways to respond to Indigenous stories which have long lives of their own. The lives of their texts are, I believe, vitalamong their many other lives.

That the kind of text I look at here-collaborative textualized orature, often published as ethnography-may offer truth and life-may offer narrative revitalization-is a key premise in my analysis. This is another reason why I juxtapose context and content to re-read these texts. In textualized orature, social context is narrative form. Thus, I take as a cue Clifford Geertz's statement that ethnography is a genre poised between the "uncertainty that appears in signature terms as how far, and how, to invade one's text [and uncertainty that] appears in discourse terms as how far, and how, imaginatively to compose it" (20). This uncertainty is a question that literary critics also grapple with. However, while literary studies and anthropology exist in a state of shared uncertainty concerning the question of mediation, they seem to me to do so with opposite premises: if anthropology entextualizes culture, literary criticism enculturates textualization.

In some of the early ethnographies I touch on in this article, there is little documentation of context: the orator, the time and place of the performance, and even the methods of the field researcher might not be indicated. Yet the content of the stories I examine here overwhelmingly concern animals, animals as human mates and as human food and as modes for human thinking - in other words, as semiotic subjects 
who desire and who consummate. Interpretive tensions in these animal-centred narratives often turn on the philosophical problem of interiority-on the problem of how to mediate intersubjectively the private subjectivities of men and women, cultures, species, and environments in these "traditional" narratives-narrative innovations over a large-scale period of time. The most decontextualized of texts, then, still carries with it in its content the power to contextualize its own decontextualization.

The tension between desire and consummation is, then, also a way to analyze the problem of intersubjectivity in the borderline between production and reception, textual transmission-because desire is, by definition, always deferred, while consummation, by definition, is always mutually conferred. By comparing conditions for interpretive uncertainty, I argue that cross-border ways of thinking with these stories enact narrative revitalization through the circulation of meaning as ontological entextualization: as "desire" and as "consummation."

\section{Euro-American Texts}

Where there's a key ... there must also be a lock (Grimm and Grimm 582).

Contact demands, before anything else, critical scrutiny of the epistemological assumptions of anthropology and literary studies inherent in the production and reception of textualized orature. As Walter Mignolo writes in his survey of spatial poetics and racialization in the Modern era, "There is no longer even the possibility of attaining and pretending to be a metacritical voice, from the left, that condemns all the failures of leftist-like discourses, pretending to find a place uncontaminated from the embodiment of existing power relations" (932). It is beyond the scope of this article to taxonomize the extent to which Indigenous and post- or neo-colonial boundaries of power are interrelated-and yet, as Mignolo continues, "border thinking [is] one possible way of breaking the enchantments and the (vicious) circle of capitalism and its internal critiques" (932). If I cannot dispense with my position as a Euro-American literary critic, and if I do not want entirely to dismiss some of the concepts and practices of my discipline, then I would like to work from where I am towards foregrounding the relations, both material and conceptual, between these bodies of Indigenous work with a view to decolonization. I intend the epigraph above to allude to narrative enchantment, where poetics and hermeneutics always seem to precede one another just as desire and consummation do-or as context and content do in literary analysis.

Lock-words and key-words often seem to fit when, in fact, they do not. Comparing locks and keys becomes paramount. This critical "movement" across uncertain borders is always necessarily provisional due to the ongoing temporal circulation and recirculation of these narratives orally-long before first contact and to this day-and in print in multiple translations and editions. Critical movement is also partly spatial-I move from the border between the European and Euro-American to boundaries archipelagic, then peninsular, and finally boreal. Thus, I begin here with key texts foundational to the formation of philology and deconstruction, two schools of thought that have influenced the course of literary studies and anthropology.

Boas states, in a 1905 lecture addressed to both anthropologists and philologists, that anthropologists must "acquire the habit of demanding such authenticity [a record of the customs and beliefs and traditions of the people in their own words] as can be guaranteed only by philological accuracy of the record" even though "in many cases this ideal cannot be obtained," leaving the "student, much 
against his will, to adopt methods of collecting which he recognizes as inadequate" (185). This tension between aural authenticity and the provisionally written stands in genealogical relation to and methodological contrast with the dual folkloristic and linguistic emphases of Boasian predecessors such as philologists Jacob and Wilhelm Grimm, for whom orality was a key to a conceptual cultural "grammar" even as they practised serious linguistic and narratological redaction in the name of socialevolutionary progressivism (Zipes 11).

The contradiction between what was desired in the aural and what was generated in print in both the Grimms' Märchen (in seventeen editions between 18121864; see Grimm and Grimm 582) and dictionary influenced the field research methods of following generations of scholars interested in the relationship between language, literature, and culture (Zipes 32). The critical borderline between originality and redaction, as the Grimms worked to transform folk tales into culturally emblematic texts, can be illustrated by their very short story, "The Golden Key" (Grimm and Grimm 582) which was, in many of the editions of the Märchen, the last of the tales and thus, in effect, the last word on their project. A half-frozen boy collecting kindling in the woods accidentally discovers a golden key beneath the snow and reasons that "Where there's a key ... there must also be a lock" (582). He finds an iron casket with a lock into which the key fits; the story ends, "and now we must wait until he unlocks the casket completely and lifts the cover. That's when we'll learn what wonderful things he found" (582). This golden key, this iron casket, this waiting, this deferral-this opening and ending, but not entirely open ending-intimate to the reader that the reader must help to constitute the meaning of the text, which, even so, will ever evade more than a partial opening up, just as the metals in the tale are not an entirely commensurate interlocking of essences: gold wears faster than iron, but iron oxidizes faster than gold.

In other words, essential and temporal asymmetries speak to the tension between desiring the philological roots of narratives and consummating that desire for them in textual analysis that is always, in part, the result of analysis that produced and therefore predicated the texts at hand. Even in 1812, then-and perhaps long before then, since versions of this folk tale likely circulated before the Grimms-there exists evidence of textual decentring in the very roots of hermeneutical semantics. Revitalization and the imputed telos, revolution, are construed by Gayatri Chakravorty Spivak (80-82) to be, as a hermeneutical default amongst some academics, offensive in the conflation of race and position. Thus, she argues that subaltern moments of silence are fundamentally a structural paradox at the horizon of post-colonial imagined experience that serves to deconstruct that imagined, "enchanted" interpretive gap. In other words, where there was believed to be a key, there would be a key, and where a lock, a lock, but never a key and a lock.

As Mignolo states at the end of his paper on modernity and tradition, there is a "catch-22 in the opposition of modernity/tradition since the categories of tradition, ritual, myth, community, and emotion are not 'realities' but categories that made possible the discourse and the very self-definition of modernity" so that "[o]ne set of terms in the paradigm describes the exteriority created by the set of terms that are the point of reference of the paradigm of enduring oppositions" even as these are "precisely the colonial conditions promoting the emergence of double consciousness and border thinking" (947). Before construing oral narratives as mythic, then, and textualized orature as reified and therefore unreliable, anthropological and literarycritical genres must undergo their own quasi-demythologization to constitute a critical co(n)text wherein the interpretive traces of orators, textualizers, and critics alike survive as intercalated sites of exchange rather than oppositional sites of mutual 
cancellation. Gerald Vizenor describes the interplay between breath and letter in Indigenous oral narratives as "survivance", the "continuance of stories" that are "prompted by natural reason, by a consciousness and sense of incontestable presence that arises from experiences in the natural world, by the turns of seasons, by sudden storms, by migrations of cranes" (11). His "sense of presence" within "situational . . chance" (11) opens a way through the binary of the subaltern and the academic to permit the "emergence of a double consciousness"-where desire as incompletion and consummation as depletion in discursive terms can be fleshed out by reading for "border thinking" itself.

\section{Haida Texts}

$<<$ This is the last I will see of you, mother, $>>$ he said.

$<<$ am going away.

Whenever I sit where the Tallgrass River reaches the sea,

No wind will blow from any direction.

The sky will be mine. (Ghandl 46)

Where Euro-American criticism begins with: Desire as incompletion, consummation as depletion, Vizenor's call to "survivance" suggests that a textual "sense of presence" has the potential to be continuous, so that desire and consummation may be reformulated as: Desire is discursive, consummation is recursive. By this, I would like to suggest that orality and literacy are not fixed practices, nor are they mutually exclusive modes, but, rather, run parallel to one another and often intersect. The story moves through media worlds and invites listeners and readers to follow it. In textualhistorical terms, Bringhurst writes, of book history in British Columbia, "[l]iterature is the animal. This is not a book about the animal. This is about the tracks" (Ocean 13), while J. Edward Chamberlin writes of oral literature that "[t]racking is a form of reading, mostly between the lines; and we all know the natural world must be read as well as listened to. But the listening required is not straightforward" ("Klahowya" 14). Chamberlin writes also that the "one thing a hunter knows when they see the tracks of an animal is that the animal isn't there," and that "learning to recognize the distinction between a thing and a representation of a thing" is "what tracking is all about" and is also "what we do when we learn how to read" ("Hunting" 67). But Bringhurst's and Chamberlin's formulations elide the cognitive work done in learning to perceive the "animal" that runs "in between the lines" that is a discursive/recursive "presence." The question of "presence" on the page is iterated in the turn from theorizing oral composition within a single performance, to theorizing verbal technē within a culture, to theorizing poetic form from grammatical markers in the post-performance textuality of narratives, to theorizing the reception of orature in its initial composition-a conceptual full circle with a difference.

The difference in the movement of theories of orality and literacy may be illustrated by four textualizers of Haida literature. John Swanton, a Boas-trained anthropologist, transcribes and, with Haida community members Henry Moody, Mary Ridley, and Henry Edenshaw, translates as prose the narratives of two remarkable Haida storytellers, Ghandl and Skaay, along with twelve other Haida orators (Enrico, Skidegate 2). These narratives are published predominantly in English in Haida Texts and Myths, Skidegate Dialect (Swanton 1905). In Swanton's collection, there are two "Texts with free and interlinear translations", twelve "Stories accompanied by texts", running facing-page translations, and several hundred pages of "Myths in English" 
(Swanton, Haida 3). It is notable that Swanton, perhaps in part due to restrictions on his time and limited space for the printing of this work, devolves quickly from "texts" that are Haida with very close English translations to "stories" that are accompanied by "texts" to "myths" that are published only in English. Implied in this terminology is an inverse relation of values between linguistic precision and artistic scope-between the alphabetical representation of written language and the metaphysical representation of Haida culture underneath the covering of another language. However, Ghandl and Skaay, and Swanton with them, form a powerful genealogical basis for subsequent expressions of and debates about Haida textualized orature. It is Swanton who first publishes, in the Euro-American medium of print, dually in English and Haida, the narrative from which I quote at the start of this section. Swanton gives this narrative the title, "How Shining-heavens caused himself to be born" (Swanton, Haida 26-31). Yet the quotation I use is translated by Bringhurst, who used Swanton's and John Enrico's work to create a smoother translation. The textualizers and translators working in these modes are sometimes opposed to one another in their desires. The desires of the orators are obscured by history, but also, in the public forum, by debates over contemporary readers' desires.

In Skidegate Haida Myths and Histories (1995), John Enrico re-elicits and retranslates some of Swanton's textualizations of Ghandl's and Skaay's narratives as prose with English and Haida versions of the narratives alternating throughout the book for the purpose of linguistic study (cf. Enrico Haida Dictionary; Enrico and Stuart). Enrico's translations draw upon community relationships with Haida Elders such as Hazel Stevens and Kathleen Hans (Enrico, Skidegate xi). Yet Enrico's concern about the collaborative boundary between "dictation" and the "form of these stories"-and the effect of their oral composition on the instance of their telling-as well as his concerns about the effects of the slowness of dictation upon syntax-simplifying - and about the obscuring effects of transcription upon the "temporal flow and rhythm and the emotional contours"-inhibiting the interpreter's "understanding" of connections between "episodes" and the "original evidence for [a narrative's] structure" (4)-are homologous to his statement that the "boundary between 'myth' and 'lineage history' is blurred somewhat by the incorporation of some episodes taken from myths into lineage histories, and by the semi-mythical nature of the early events and individuals they describe" (4). Thus, text and context must constantly be recontextualized. In Enrico's mid-90s publication, at least, he is skeptical of "Boas' preferred solution [to the problem of dictation] . . . to have consultants literate in their native languages supply him with texts, apparently feeling that literacy and writing would have no effect on the form of these" (4). He is so skeptical of these verbal and structural distinctions that he bases his prose work primarily on his relationships with Haida Elders. Yet he fails to quote their own words on these important questions. Although his respect for these Elders is manifest in every page of his publication, and although there are, no doubt, many years of good relationships contextualizing the book, readers must trust Enrico's assertions concerning his relational methodology, being forced to trust him as a scholarly figure and cross-cultural friend or doubt the narratives themselves. Is this his desire? It seems unlikely, but while his narrative desires are well-defined in his introduction to the narratives, the nature of their textual consummation is open to as much surmise as are the narrative desires of the Haida Elders with whom he works.

Enrico comments on some links between animals and metaphysics in relation to Ghandl's narrative, which he titles, in his English translation, "Spirit of the Atmosphere Who Had Himself Born," where animal skins hold the power to transform borders between beings. His comment illustrates the tension between narrative 
presence and textual absence in the terms with which I began this section. Enrico asserts that "there was no general term for those [spirits] of the sky," but that sky spirits had earthly forms just as earth and sea spirits "had earthly forms as sea creatures and forest creatures, assuming their spirit forms only when in their spirit realms" (7). Thus their "spiritual aspect consisted in their raahlaandaay or 'soul', their earthly aspect being their "skins'" (7). Enrico adds that the "usual story metaphor for the passage of one of the spirit/animal beings from spirit to earthly realm is the putting on of its skin" (8), distinguishing between metaphysical spirit and flesh even as he conflates them in his description of narrative metaphor, where skins are a matter of ontology as much as of textuality. However, he does state that the Spirit of the Atmosphere is the spirit from whom "all other spirits received their 'power'" (8), and, in so doing, demonstrates, at a textual level, the tension between discursive and recursive interpretation-which is the same tension as that between belief in spirits and in the figuration of spiritual beings: as Weather puts it, "<<This is the last I will see of you, mother, $>>$ he said. I $<<1$ am going away." Weather's departure into the sky is an end that predicts his beginning: there is no out-side to transcendence and no out-side textualized orature, once it has come into being. Yet where some instances of literary interpretation are a demonstration of hermeneutical emptiness, other instances of transformation are a demonstration of departure that is immanent with potential meaning.

Bringhurst, as a contemporary poet and literary translator, applies the principles of ethnopoetics in his verse translations of the narratives of Ghandl (2000) and Skaay (2001). Bringhurst also published a companion volume of criticism on Haida oral literatures, A Story as Sharp as a Knife: The Classical Haida Mythtellers and Their World, a text that is informative, incisive, even visionary, but which sometimes lacks detailed citations of the scholarship that Bringhurst draws upon to form his commentaries. This dearth of citations serves, at times, to foreground Bringhurst's own poetic thought rather than the Haida or Euro-American thinkers whose philosophies, ethnographies, zoologies, geographies, and botanies (short-hand terms for traditional ecological frameworks and knowledge as well as scientific frameworks and knowledge) he draws upon. A perfect example is his statement that "by donning such a blanket [as a naaxiin, "a figured blanket," also called a Chilkat blanket]—such an animated skin-a skinless human being is empowered to cross the xhaaydla, to pass from realm to realm, like a sea mammal or a bird" (Bringhurst, $A$ Story 102). Bringhurst's intimation of the metonymical powers of material, symbolic, and ontological transformation is brilliant, but he does not cite any primary, literary, or anthropological sources for this assertion. And he does not include full Haida-language texts in his publications. Perhaps this is more than merely ego: if scholarly decolonization recognizes science and history to be contested genres of contested interpretations, Bringhurst's statements on myth, such as the one I offer below, renders as present the elusive effect of narratives that run between the lines, so to speak, so that printed form (prose, verse) reveal Lévi-Strauss's Derrideanized assertion that in mythopoeia "[t]here exists no veritable end or term to mythical analysis, no secret unity which could be grasped at the end of the work of decomposition" (Lévi-Strauss qtd. in Derrida, "Structure" 233). No end, and no beginning, but much becoming, for "[i]f history adheres to events as understood or as reported," Bringhurst asks, "what does myth adhere to? To the history of history? To the fact of repetition?"-and he then proposes that a "myth is a pattern of meaning that reproduces itself: a pattern that refuses to stop meaning, or in other words refuses to die out" (360). After much debate in Haida and Euro-American forums concerning Haida protocols for narratives and Euro-American copyright laws for texts (Spencer, 
"Orality" 300), a portion of Skaay's narratives were retranslated and published by Bringhurst in 2007 as Siixha, Floating Overhead: The Qquuana Cycle 3.3. It is a duallanguage publication.

Carol Eastman and Elizabeth Edwards, with Alaskan Haida Elders, including Lillian Pettviel, textualize in dual-language form a selection of Haida narratives that are simultaneously traditional and contemporary, "illustrat[ing] the way Haida narrative structure incorporates Western oral genres" (7), in Gyaehlingaay: Traditions, Tales, and Images of the Kaigani Haida (1991). Eastman and Edwards state that the "narrative selections in this volume are byproducts of our linguistic research and a natural outcome of our close friendship" with Haida orators (1) and that the "stories we present as reminiscences were told spontaneously while we were listening to, and attempting to participate in, conversations among several Haida speakers" (3). While these stories are rather short and heavily contextualized by scholarly commentary, this publication serves to illustrate three important points: first, "traditional" Haida orature is adaptive and ongoing (7); second, Haida orature as a formal medium is mobile and often concerns cultural mobility: these stories are examples of mainland Haida orature spoken in the Kaigani, or Alaskan, dialect of Haida (1) by Haida people living in Alaska, Haida Gwaii, Seattle, and San Francisco (3), concerning, for example, migration from the archipelago of Haida Gwaii to the mainland (13-18); and third, Haida orature expresses the mobility of cultural practices that informed Ghandl's story of "The Way the Weather Chose to Be Born". The Weather's apotheosis began in a mollusk-he began as a changeling in a shell. Upon shooting his first bird and donning its feathered skin, he begins to move out to the horizon. It is his adoptive mother-his family of one-who forges for him and arms him with a copper bow and arrow and who celebrates his hunts. This practice is reminisced upon in historical terms in Eastman and Edward's stories "First Kill" (21-23 in English; 78-79 in Haida) and "Mother's Brother's First Kill" (24 in English; 80 in Haida). The first narrative begins, in the English translation: "A long time ago when a boy child first killed something, they honoured him for it ... they celebrated with him because they thought so highly of it"; and it ends with "they show off with the thing the small boy killed. That is the way they honoured his deed. They 'give him the day.' That is what they call it" (21). This beautiful phrase, "they 'give him the day"' —in Haida, "laa tl' singáada" (79)—bridges the historical and metaphysical implications of Ghandl's narrative because it illustrates the connection between life lost and gained. At the confluence of cosmological borders, narrative desire as textual consummation is often construed as absence for presence: "where the Tallgrass River reaches the sea," Weather is able to still the wind-"No wind will blow from any direction"-and transfix the sky by his presence-"The sky will be mine." Weather's birds, both within and outside the line between land and sky, become skins for the lifting of spirit past the borders of human and animal ways of making meaning.

\title{
Tlingit Texts
}

\author{
No! \\ It is not right \\ for them to do this to me. \\ Yes. I am not the same anymore as I used to be. \\ When \\ I pull on \\ my husband's skin \\ I don't think my old thoughts any more.
}


This is why. No!

Let me be.

Let me live among you for as long as possible. (Peters 189)

If it is assumed that animals are both within and outside of human discourse-at the motive levels of metaphor and of material (whether as food for an individual or a community or as plastic resources for symbolic representation), then it may also be true that humans are in and outside of animals' fractional wholenesses too. In the epigraph above, a woman has married a bear, had children with him, betrayed him, and returned to her human family. It is a difficult adjustment because her old human family cannot understand her new bearness. They cannot understand that the perspectives she gains upon donning the skin of a bear have changed her-and continue to change her-at an ontological level. They cannot accept that her desires are now both human and animal. Here, the antagonists of the narrative are also impediments to interpretive interlocution; they cannot understand that, at a hermeneutical level: Desire is coeval with consummation.

In other words, these antagonists cannot understand that positionality-the positions of personal identity, of textual artistry, or of hermeneutical commentary-can be constituted by fundamentally paradoxical values. The wife of the bear holds-until she is killed by her own family-multiple perspectives simultaneously; she is both nakedly human and an animal enrobed in itself. In this example, I find one of the keys to the problem of borderlands: I suggest that, rather than absence for presence, this example of Tlingit textualized orature might be read as the product of multiple presences or positionalities. Eduardo Viveiros de Castro writes that "Amerindian thought" holds that "animals must still be human, albeit in an unapparent way"; that "the manifest bodily form of each species is an envelope (a 'clothing') that conceals an internal humanoid form"; that "[t]his internal form is the soul or spirit of the animal: an intentionality or subjectivity formally identical to human consciousness"; and that "animals have a human, sociocultural inner aspect that is 'disguised' by an ostensibly bestial bodily form" (465). While I do not wish to conflate all Indigenous epistemologies of being and becoming, I would like to consider, across the Tlingit/Amazonian border, the idea that subjectivities imbue intention with formal qualities akin to animal kinds. In this figuration of skins, human consciousness is naked; animal consciousness is clothed. Humanity and animality, then, are interconnected by degrees of nudity or intentionality. To undress for and address another across species boundaries are related acts, related by a desire for reciprocal response, for an emergent consummation of interiorities personal, tribal, ontological, conceptual.

At the level of narrative, internal form is that which can never be fully ascertained, but it can at least be acknowledged-described receptively-as the touch of the other against the self. This is the internally comparative approach that Nora Marks Dauenhauer and Richard Dauenhauer take in their Classics of Tlingit Oral Literature Series (Haa Shuká, Haa Tuwunáagu Yís, Haa Kusteeyí). In Haa Shuká, Our Ancestors: Tlingit Oral Narratives, careful editing and translating of narratives by Tlingit orators honours the individual desires of the orators (cf. Swanton, Tingit Myths). The Dauenhauers make known their own desires in their Preface: "We are involved in Tlingit oral literature because we believe it has value, that it is a treasury of spiritual gifts from which we can draw in times of need," while they are careful to assert this is for the "Tlingit people especially, and especially the youth, [that they] may find comfort and reward in how their ancestors faced decisions in their lives" (Haa Shuká ix). This statement borders on faith, where the past testifies to the future for the sake of the 
present, testimony which is expressed as a matter of genre. The most important Tlingit genre is defined in terms of "at.óow" an "owned or purchased thing" (26), or, more inclusively, the "ancestor, the design, the spirit of the animal, the song, the story, etc., and the land where it happened" (26) - things that must be attested to-fostered and passed on. The Dauenhauers also identify and define two other important terms, "shagóon" and "shuká", which mean, respectively, one's human ancestors and one's progenitors in a "two directional" sense (28). "Shuká," they write, "means, most literally, 'ahead,"' referring to "that which has gone before us in time-predecessors, those born ahead of us who are now behind us" but also "that which lies ahead, in the future" (28). Here is a temporality of consummation that honours individual connections over a history that is both the past and the future. The Dauenhauers also include biographies for each orator. As well, the narratives are published both in Tlingit and English in facing-page chapters because the Dauenhauers believe that "it is very realistic to expect that many people in coming generations will learn to read and appreciate the ancestral language through study of the classics of the past," adding that they believe "it is reasonable to hope that in the meantime families and communities will work together to cultivate their traditions, whether in English or Tlingit, working with their living elders, and with the documented inheritance of the past" (xi). Thus, the "documented inheritance" is always already multiperspectival in content.

Multiperspectivism can also cross generic borders. Julie Cruikshank writes: "potentially, an oral history attuned to narrative conventions provides an observatory from which to assess the shifting boundary between what we call history and what we call myth" (Preface $\mathrm{x}$ ). She adds that in the context of what it means not just to be human but to articulate what it means to be human, "recording a life history is usually a social activity," which is a "collaborative product of an encounter between two people, often from different cultural backgrounds," so that the text "incorporates the consciousness of an investigator as well as that of a subject" (x). Thus, while "orally narrated life histories are too often written as though the narrator were addressing the cosmos," in fact, such "narration is occurring in a very specific context"-that is yet "more than just the spontaneous product of an encounter between an interviewer and a subject," for the "narrative has symbolic qualities-a kind of autonomous life that simultaneously reflects continuity with the past and passes on experiences, stories, and guiding principles in the present" (x; cf. McCall 21; Fredson; Lowie; Moore; Tyone). This "autonomous life" in the "symbolic qualities" of the narratives happens at the boundaries of past, present, and future. Angela Sidney, Kitty Smith, and Annie Ned, with whom Cruikshank worked, recorded their desires for recording their life stories as well as traditional stories, so that, here, desire and consummation may be construed as a form of transmission that seems to travel in two directions. Between the intersubjective, collaborative context and the "cosmos" is a continuity between the genres of "myth" and "history." Indeed, Sidney, Smith, and Ned's Tlingit and northernDene identities find expression in personal context as cosmos-as Cruikshank writes, "meanings do not inhere in a story but are created in the everyday situations in which they are told" (Social xv; cf. Nyman and Leer 5, 101). This combination of before-life and now-narratives is a profoundly existential expression of narrative desire without any certainty of textual consummation. Sidney, Smith, Ned, and Elizabeth Nyman (Nyman and Leer) witnessed and participated in unimaginable historical changes over the duration of their lives and yet they found continuities akin to shuká so that their autobiographies can assert, transformatively: "Yes. I am not the same anymore as I used to be"; yet also: "Let me be." 


\section{Northern-Dene Texts}

"What will you do now?" Wolverine asked. ... He sealed the wound with his saliva, then blew on the wounds in a magical way. (Moore and Wheelock 31)

Transformations at the levels of perspective and ontology are recurring themes in this article and in the context and content of textualized orature. Changes occur in the production, transmission, and reception of these narratives as they change "skins"but also as they travel forward through human generations. One of the ways that the reception of these stories is constantly changing or transforming is through the translation of the narratives from source languages (Haida, Tlingit, northern Dene) to a target language (English). But these stories are also being transformed when they are translated back into their target language by language-learners working on language revitalization. Dual-language texts facilitate this back-that-is-forwards becoming best. I would like to suggest that dual-language texts that offer a line-by-line or sentence-level correlation between the two languages are most conducive to translation into the source language and, therefore, transformation. In metaphorical terms, if facing-page publications constitute narrative desire and textual consummation, perhaps interlinear text is a birth, a grammar a family, a dictionary an afterlife, translation a re-birth, and re-translation an apotheosis. It is the idea of rebirth that I want to focus on in this section because rebirth or reincarnation of both humans and animals is an important form of expressing a spatial and temporal duality of uncertainty, grief, and hope within many northern-Dene narratives (Goulet, "Reincarnation" 172; Goulet, "Ways" 116; Mills; Ridington and Ridington 363-64). If it is hoped or desired that the narratives northern-Dene orators share with transcribers will be of use to future generations, then I believe these narratives hold the potential for narrative revitalization as well as language revitalization. Of course, the ways that narrative revitalization might occur are as many as there are readers and speakers of the narratives, but in the recurring theme of rebirth-revivification, reincarnation, reinscription-at work in so many northern-Dene narratives, I see a cue to construe: Desire and consummation as cyclical.

Peter Kalifornsky's Dena'ina narratives contain a fascinating combination of coastal animal tropes in the framework of northern-Dene epistemologies, which are, in part, based upon dreaming, prophecy, migration, and renewal. Kalifornsky's textualizations of traditional narratives in his Dena'ina language are unique because the Dena'ina language-culture group is the only northern-Dene group that is traditionally oriented to the Pacific Ocean. If some coastal narratives have a glassy, iridescent, incised effect and narratives from the interior a tawny, rolling, rough effect, Kalifornsky's combine these traits in compressed philosophies to enact renewed relationships between beings. These beings include a number of kinds of human thinkers—shamans, dreamers, prophets-and animals. A Dena'ina Legacy: K'tl'egh'i Sukdu by Kalifornsky with James Kari includes a number of Kalifornsky's key works in all genres; it is a dual-language book with translations by Kari and Kalifornsky. One of the first narratives in the collection, "The Old Dena'ina Beliefs" (Kalifornsky 12-17), highlights the connection between belief and rebirth, narratives and renewal, through the painful crucible of personal and collective risk of disaster. The story begins: "Whatever they [people who desired to become shamans] wanted to be as they were growing to adulthood, they fasted and tried to become that"-they "tried to have shamanistic dreams, to speak words that would become true, and to read the stars. 
And they always fasted" because "[w]hatever is on this earth is a person [has a spirit], they used to say. And they said they prayed to everything. This is the way they lived" (13). In doing so, in pain, in articulating inner truths, in desiring contact with every kind of animal and land feature without consuming these entities as physical sustenance, "it would become clear to them, what they were trying to become, and they would keep their minds set on it" (13). Kalifornsky emphasizes that this process is fraught with danger and the risk of violence: "To try to become good is dangerous. Struggling against evil is dangerous"-he states, for example, that such seekers "began to have nightmares, and they would suffer for a long time," until "finally they would become what they were trying to be" (13). I would like to suggest that this struggle is, in part, a practice of dying and returning to life within the realm of the text as well within the realms of life and of death. One can die while alive and one can come to live again after death. Reincarnation and reinscription are juxtaposed within both the content and context of the text.

If dreaming is a referential practice, it is also a discursive one in which ways of being and points of view are constantly unmade and remade, much as animals are hunted, killed, eaten, and, according to Kalifornsky and other northern-Dene storytellers, reborn. He writes that the "Dena'ina, they say, had some beliefs about animals," which involved "put[ting] the bones in one place" so that the "animals would be in good shape as they returned to the place where animals are reincarnated" (41). Treating animals and their skeletal traces with respect works at a physical level, but it seems to me that the value also operates at a narrative level, where exchanges between humans and animals demand forms of perceptual empathy that inscribe upon the perceiving mind-the hunting human-a sense of systematic corollaries between life and death. These corollaries imbue one's limitations of perspective with the sense that being itself is penetrable and cyclical until the afterlife makes life seem like the before-life, skins that recollect skeletal structures, and pages retrace visionary semantics (cf. dream maps in Brody). Kalifornsky explores the work of perception itself in his poem "Thought: How It May Be" by asking the philosophical question: "Suppose: what if-false or true?" (Kalifornsky 455); and then tracing how thinking occurs. He proposes: "What is / at the moment / all at once" may well "happen all at once / all at once, bad / all at once, more so"; so that perception occurs "all at once, the opposite way / all at once, it is unresolved [literally 'it will be'] / all at once, it is undecided [literally 'it became']" (455). In this stanza, Kalifornsky demonstrates a sensitivity to deconstructive thinking that must recognize that all oppositions, "false or true", or "the moment" and "all at once", are both "unresolved"—and will be-and "undecided"—and have always already become.

In the oppositions of animal life and death, flesh and bones, empathy and hunting, Kalifornsky suggests, in the words of another of his poems, "The Work of the Mind": "Our body and brain come together [to make the mind]. / Through our senses we become totally aware. / The world is represented in our mind and becomes part of us"-and so "we imagine" (457). Although Kalifornsky plays within decentred oppositions in his narratives and poetry, he also moves beyond purely decentring discourse in the next lines of the poem. He suggests: "When that [imagination] happens, / there is transformation into awareness. / Then the body and brain become one whole," and the "result is something higher-it goes beyond" (457). The lesson of animal reincarnation, then, within the context of Kalifornsky's poetics, may be that narrative desire and textual consummation are always impermanent but also have the potential to always be on the move. Written text can be taken up again in spoken language and always already has been. The risk is in whether one kind of 
impermanence will prevail. The potential reward is an overleaping of the bounds of limited subjectivity - to "go [. . .] beyond."

In Wolverine Myths and Visions: Dene Traditions From Northern Alberta, Patrick Moore and Angela Wheelock describe the narratives contained therein in generic terms that also index beliefs about going beyond and coming back again: they state that "all Dene Dháa stories are classified as wodih 'stories, lectures, news,' a category which includes accounts of recent events, hunting stories, moral lectures, and prophecies as well as traditional stories," adding: "Wodih are used to influence an audience by establishing a common base of belief, by sharing the experiences of others, and by suggesting what will happen in the future"-and "Wodih can be contrasted with shin 'songs,' which are used primarily to address spirits" (Moore and Wheelock xix). Moore and Wheelock add that traditional narratives are called "tonht' onh wodihée "stories of long ago," and that "[t]his subclass of wodih includes all the stories about animal people and culture heroes" as well as including "stories about people who are no longer living or about events which occurred many years ago" (xix). From this definition of Dene Dháa stories, I think that belief is shaped by "news" from the past and the future-beliefs about wolverine, in particular, in this collection. Wolverine signifies both human and more-than-human power, for "Wolverine is a trickster and cultural transformer in Dene tradition, much like Coyote in Navajo or Raven in Northwest Coast traditions," because "Wolverines may destroy people's traps and furs and ruin their belongings, yet paradoxically in stories Wolverine also has great powers of transformation" (xi). In human terms, the prophet "Nógha 'Wolverine' became the leader of the messianic Tea Dance religion in northwestern Alberta," while in narrative terms, "[o]ne storyteller said about the animal Wolverine, 'His tracks go on and on, back to the time before people were living here.' The stories lead the reader back to that time" (xi). Here, again, is a powerful connection between the past for the future through reinscriptions about reincarnation animal-centred and print-based.

I shall focus on two stories from Wolverine Myths and Visions that illustrate the cyclical working of reincarnation and reinscription. In "Wolverine Steals a Child" (1321 in English; 122-40 in Dene Dháh), a father pursues the trickster Wolverine and then some giants who are physically conjoined in order to get his child back. Twice the child dies, and once the father is able to revive him through shin: "he gathered together all of his son's bones, including his skull. Then, preparing a place to sleep, he prayed for his son. He concentrated completely on prayer," which runs: "I wish my son would live again. I I wish I could talk to him in the morning. I I wish he would be restored just as strong as ever come morning" and ends: "I wish he would live again" (20). The father then "slept, placing his son's bones beside him under his blanket" and "falling asleep away from his son's bones" (20). In this story, pursuit, hunger, cannibalism, grief, hope, and desire with the strength of faith combine to precipitate the revival of the younger generation. The father's treatment of the remains of his son is as it should be-he gathers all of the bones up together, as all hunters should do with the bones of their quarry, and then he opens himself to the less visceral traces of his son by singing from his heart and then sleeping in close proximity to the bones. In the cyclical habit of sleep that is akin to the cyclical patterns of light and dark, life and death, the father is able to re-articulate his son's presence within his son's bones.

In another story in Moore and Wheelock's collection, "The Man Who Sought a Song" (28-35 in English; 155-74 in Dene Dháh), a young man is told by his father to go into the bush to seek a vision of an animal in order to guide the young man through his life. The young man is met with bewildering silence in his sleep and eventually, in 
wandering the bush, is killed and dismembered by a camp of beings who then urinate on-essentially desecrate-his remains (30). The desecration of his remains is an important point, because, as I cite above, the mind or spirit cannot be reincarnated in the body without right behaviour, respect for the body and the desire for wholeness. Wolverine, the same trickster who precipitated the son's misadventures in "Wolverine Steals a Child", comes upon the young man with Wolf. The dreamer is restored lingually and with the transfer of breath. Near death, the "young man heard this pattering sound as he lay there," and then Wolverine speaks to him, saying: "Like me, you take in filthy things" (31). Wolverine heals the young man by "run[ning] around him singing," and then "gnawing the frozen urine in the young man's chest" as well as "lick[ing] inside the young man's stomach, inside his heart" (31). Wolf "joined Wolverine and put the young man's ribs back together," and Wolverine "sealed the wound with his saliva, then blew on the wounds in a magical way" (31). And this happens, the orator of the narrative states, because "[t]his was also part of the young man's vision, that he should learn through suffering" (31). There is a cost which comes with a vision.

Suffering is the precipitate (in the senses of urine, saliva, blood, snow, copper) of learning in other northern-Dene stories too. However, tracing such narrative themes requires careful exploration of the bibliographical context (see e.g. Mandeville Chipewyan Texts; This Is What They Say). And when these narratives circulate in multiple versions, these questions must be asked many times. It is important to acknowledge that many versions of oral narratives cannot be inducted into academic modes of analysis, either because they circulate within northern-Dene community contexts or according to cultural protocols that exclude participation in a typically academic mode for academic ends, or because they have not been documented in ways that the academy has indexed. At the same time, I believe textualized orature has entered into a shared "told-to" tradition to convey powerfully transformative ideas from the "told-by" communities and cultures and are deserving of ongoing attention through academic as well as other modes of engagement. If many northern-Dene narratives demonstrate outcomes of interpretive transformation or even rebirth through language as technē, a tool for investigating and navigating the world (Ridington, "Dogs" 188; Ridington, "Tools" 212-13), then open, even oppositional, questions are the key to cyclical narrative desire and textual consummation.

For example, the questions: Are you ready to live? and: Are you ready to die? are oppositions that, in their extremes, tend to meet, overlap, and amplify two ultimately interchangeable answers: Always! and: Never! into one sign: Maybe-a form of semiotic reconditioning. In Dane-zaa narrative expressions of reincarnation, the culture hero Tsááya, whose animal guide is the swan, leads dreamers-visionary prophets and Elders - to hunt the swan as it migrates between hemispheres, in their dreams that rise up from the earth into heaven ahead of the sun (Ridington and Ridington 25-26). Dane-zaa cultural practices include dreams of heaven as narratological and vocalic prophecies for life here on earth that are contextualized by teachings about the reincarnation of humans and animals and about the power of the culture hero, Tsááya, who began the work of reincarnation and of renewal. Part of Tsááya's narrative figuration is to transform worlds spatial, temporal, perceptual, and ontological. The nature of his transformative effect is at once generative and destructive; he comes into power through suffering, while the renewal of his role of culture hero occurs through the resignification of his power at the level of the revitalization of his narratives in contemporary Dane-zaa media. I would like to suggest that teachings about Tsááya demonstrate the complexity and power of a more-than- 
human epistemological system which, in an era overwhelmingly defined by the human (and by the emergence of nonhumans), is actually part of a continual recirculation of re-emergent meaning that has always already been embodied by the flight of the swan. And in its song.

Some teachings about Tsááya were recorded in the 1960s by Euro-American anthropologist Robin Ridington (1939-), and Dane-zaa Elder Charlie Yahey (18811976), in Dane-zaa Záágé?, and translated into English by Tommy Attachie (1943-). Flight serves as Tsááya's imperfect yet puissant conduit to cyclically overcoming his human limitations in the past: and for the sake of humanity, he continues outside of historical time, waiting to return when giant monsters-such as those released by oil and gas extraction technologies-have reached their peak (Ridington, Swan 85, 119; Ridington and Ridington 43-44). Dane-zaa cultural poetics and hermeneutics have only increased in the context of oil and gas exploration and extraction (Doig River First Nation). But not all technologies of mediation (of earth, animal, human, or giant) are destructive. Yahey recognized Ridington's contribution to Dane-zaa narrative in the form of audio recordings to be a new source of reinscription and recirculation. Yahey states that the "sun is going down and turning red. When I look at this my tears come down" and adds that there are "people like me going to find the road but for a long time, many times I have told them what is going on but I tried to help these people down here when I dream" (Ridington, Swan 76). And he warns that "I will not live long. I am sending messages to other people with this tape recorder" (88). Compare Yahey's words on the power of allegorical mediation to another prophet's words: "From the sun I learned this: when it goes down, so over-rich; gold it scatters then over the sea out of inexhaustible riches" so that "even the poorest fisherman still rows with golden oars! For this I saw once and did not weary of my tears in watching," and thus, "[l]ike the sun will Zarathustra too go down: now he sits here and waits, with old shattered tablets about him and new ones too-half-inscribed" (Nietzsche 172). These parallel images are connected in ways that I have yet wholly to comprehend; Yahey could not read, but it is possible that similar solar logics inform these prophetic calls to remediation. I think, although Ridington's textualizations of Yahey's narrative visions are inevitably imperfect, Tsááya's transformative purposes are served in the intersubjective nature of oral-textual mediations through which pass Yahey's dreams of guidance. Yahey comments, concerning the transmigratory guidance of swans, that "[n]ot only us pray to God- / even swans [do], when they have hard luck in the fall time / and start to starve," for swans "can just go right through the sky to heaven without / dying" (Ridington and Ridington 26-27). To return to the epigraph at the beginning of this section and to the question of how to be, how to move, how to become whomever one is becoming-how to move with pain-"What will you do now?"-is to return to the answer as well, which is found in the breath between planes of experience where one is to "bl[o]w on the wounds in a magical way" —or to pray to "go right through the sky to heaven without / dying."

\section{Conclusion}

I would like to return to Mignolo here and the application of his border thinking to the question of intersubjectivity. He states that the "epistemic potential implied in the genealogy of knowledges that has been subalternized from the perspective of modern epistemology," so that "epistemic potential grounded in what for modern epistemology has been silence and darkness ... [is] disinherited by and through the emancipation claims of modernity" (948). And yet these are the silence of desire and the darkness 
of consummation, perpetuating truths that neither dispense with nor succumb to the enchantment of print or the semiotic deconstruction of print by the power of speech. For the border crossing from being into meaning enacts the intercalation of narrative desire with textual consummation. This is the point. This is, from one perspective, at least, why women-and sometimes men-marry bears; why trapped hunters climb into seal skins and look out the eyeholes; why wolves and wolverines can lick the ice out of the hearts of lost dreamers who have been splayed open and left for dead on the snowy earth of winter landscapes. The crux of the conflict in these narratives is learning exactly whom to address and how. And often the moment of understanding comes when the protagonist at last realizes that it is they who have been addressed all along, if only they could hear the voices of their guides (animals, landfeatures, texts) in the right ways and with a good response. Likewise myself as reader. Interpretation itself is likewise an act split into autonomous halves-like the two troubled but essential parts of the sign-the sign that paradoxically yet essentially binds together pedagogue, student, text, orator, transcriber, and reader in a skin to make a body renewable by virtue of its own internal differences between being, beings, and becoming. Becoming across these spaces is "border thinking," and is thus, as Mignolo argues, "one possible way of breaking the enchantments and the (vicious) circle of capitalism and its internal critiques" (932). Thus, even the decolonial poetics of orature might allow for at least the inception of ontological entextualization for the sake of narrative revitalization.

\section{Works Cited}

Boas, Franz. "Some Philological Aspects of Anthropological Research." A Franz Boas Reader: The Shaping of American Anthropology, 1883-1911, edited by George W. Stocking, Jr., Basic, 1974, pp. 183-88.

Briggs, Charles L., and Richard Bauman. "Genre, Intertextuality, and Social Power." Journal of Linguistic Anthropology, vol. 2, no. 2, 1992, pp. 131-72.

Bringhurst, Robert. Ocean, Paper, Stone: The Catalogue of an Exhibition of Printed Objects Which Chronicles More Than a Century of Literary Publishing in British Columbia. Hoffer, 1984.

---. A Story As Sharp As a Knife: The Classical Mythtellers and Their World. Douglas, 1999.

Brody, Hugh. Maps and Dreams: Indians and the British Columbia Frontier. Pantheon, 1982.

Chamberlin, J. Edward. "Hunting, Tracking and Reading." Literacy, Narrative and Culture, edited by Jens Brockmeier, Min Wang, and David R. Olson, Routledge, 2002, pp. 67-85.

---. "Klahowya Tillicum: Coming Home to the Stories and Songs of the West Coast." 26 Feb. 2009, University of Victoria, Victoria, BC. Printed Lecture.

Cruikshank, Julie. "Preface." Life Lived Like a Story: Life Stories of Three Yukon Native Elders, by Angela Sidney, Kitty Smith, Annie Ned, and Julie Cruikshank, U of British Columbia P, 1990, pp. ix-xii.

---. The Social Life of Stories: Narrative and Knowledge in the Yukon Territory. 1998. U of Nebraska P, 2000.

Dauenhauer, Nora Marks, and Richard Dauenhauer, editors. Haa Kusteeyí, Our Culture: Tlingit Life Stories. U of Washington P, 1994. 
---, editors. Haa Shuká, Our Ancestors: Tlingit Oral Narratives. U of Washington P, 1987.

---, editors. Haa Tuwunáagu Yís, for Healing Our Spirit: Tlingit Oratory. U of Washington P, 1991.

Derrida, Jacques. "Structure, Sign and Play in the Discourse of the Human Sciences." Writing and Difference, 1967, translated by Alan Bass, Routledge, 1978, pp. 278-94.

Doig River First Nation. Dane Wajich, Dane-zaa Stories and Songs: Dreamers of the Land. Virtual Museum of Canada, 2007.

Eastman, Carol, and Elizabeth Edwards. Gyaehingaay: Traditions, Tales and Images of the Kaigani Haida. U of Washington P, 1991.

Enrico, John. Haida Dictionary: Skidegate, Masset, and Alaskan Dialects. Alaska Native Language Center, 2005.

---. Skidegate Haida Myths and Histories. Queen Charlotte Islands Museum, 1995.

Enrico, John, and Wendy Bross Stuart. Northern Haida Songs. U of Nebraska P, 1996.

Fee, Margery. "Romantic Nationalism and the Image of Native People in Contemporary English-Canadian Literature." The Native in Literature: Canadian and Comparative Perspectives, edited by Thomas King et al., ECW, 1987, pp. 15-33.

Fredson, John. Stories Told by John Fredson to Edward Sapir, edited by Jane McGary, Alaska Native Language Center, 1982.

Ghandl. Nine Visits to the Mythworld: Ghandl of the Qayahl Llaanas. Translated by Robert Bringhurst, Douglas, 2000.

Geertz, Clifford. Works and Lives: The Anthropologist as Author. Stanford UP, 1988.

Gingell, Susan. "Teaching the Talk that Walks on Paper: Oral Traditions and Textualised Orature in the Canadian Classroom." Home-Work: Postcolonialism, Pedagogy, and Canadian Literature, edited by Cynthia Sugars, U of Ottawa P, 2004, pp. 285-300.

Goulet, Jean-Guy. "Reincarnation as a Fact of Life among Contemporary Dene Tha." Amerindian Rebirth: Reincarnation Belief Among North American Indians and Inuit, edited by Antonia Curtze Mills and Richard Slobodin, $U$ of Toronto $P$, 1994, pp. 156-76.

---. "Ways of Knowing: Towards a Narrative Ethnography of Experiences among the Dene Tha." Journal of Anthropological Research, vol. 50, no. 2, 1994, pp. 11339.

Grimm, Jacob, and Wilhelm Grimm. "The Golden Key." Complete Fairy Tales of the Brothers Grimm. 1812-1857. Translated and edited by Jack Zipes, 3rd ed., Bantam, 1992, p. 582.

Harpham, Geoffrey Galt. "Roots, Races, and the Return to Philology." The Humanities and the Dream of America. U of Chicago P, 2011, pp. 43-79.

Kalifornsky, Peter. K'tl'egh'l Sukdu: A Dena'ina Legacy. Alaska Native Language Center, 1991.

Kroeber, Karl. "Interview with Karl Kroeber." The Dispatch: The Newsletter of the Center for American Culture Studies, vol. 6, no. 1, 1987, pp. 5-8.

Lowie, Robert H. Chipewyan Tales. American Museum of Natural History, 1912.

Mandeville, François. Chipewyan Texts. Translated by Li Fanggui and Ronald Scollon, Academia Sinica, 1976.

---. This Is What They Say: A Story Cycle Dictated in Northern Alberta in 1928. Translated by Ronald Scollon, Douglas, 2009. 
McCall, Sophie. First Person Plural: Aboriginal Storytelling and the Ethics of Collaborative Authorship. U of British Columbia P, 2011.

Mignolo, Walter D. "The Enduring Enchantment: (Or the Epistemic Privilege of Modernity and Where to Go from Here)." The South Atlantic Quarterly, vol. 101, no. 4, 2002, pp. 927-54.

Mills, Antonia. "A Preliminary Investigation of Cases of Reincarnation among the Beaver and Gitksan Indians." Anthropologica, vol. 30, no. 1, 1988, pp. 23-59.

Moore, Patrick, editor. Dene Gudeji: Kaska Narratives. Kaska Tribal Council, 1999.

Moore, Patrick, and Angela Wheelock, editors. Wolverine Myths and Visions: Dene Traditions from Northern Alberta. U of Alberta P, 1990.

Nietzsche, Friedrich. Thus Spoke Zarathustra: A Book for Everyone and Nobody. 1885. Translated by Graham Parkes, Oxford UP, 2005.

Nyman, Elizabeth, and Jeff Leer. Gágiwduł.àt, Brought Forth to Reconfirm: The Legacy of a Taku River Tlingit Clan. Yukon Native Language Centre, 1993.

Peters, Tom. "The Woman Who Married the Bear." Haa Shuká, Our Ancestors: Tlingit Oral Narratives, edited by Nora Marks Dauenhauer and Richard Dauenhauer, U of Washington P, 1987, pp. 166-217.

Ridington, Robin. Swan People: A Study of the Dunne-za Prophet Dance. National Museum of Man, 1978.

---. "Dogs, Snares, and Cartridge Belts: The Poetics of a Northern Athapaskan Narrative Technology." When You Sing It Now, Just Like New: First Nations Poetics, Voices, and Representations, edited by Robin Ridington and Jillian Ridington, $U$ of Nebraska P, 2006, pp. 188-206.

---. "Tools in the Mind: Northern Athapaskan Ecology, Religion, and Technology." When You Sing It Now, Just Like New: First Nations Poetics, Voices, and Representations, edited by Robin Ridington and Jillian Ridington, $U$ of Nebraska P, 2006, pp. 206-20.

Ridington, Robin, and Jillian Ridington in collaboration with Elders of the Dane-zaa First Nations. Where Happiness Dwells: A History of the Dane-zaa First Nations. U of British Columbia P, 2013.

Skaay. Being in Being: The Collected Works of Skaay of the Qquuna Qiighawaay. Translated by Robert Bringhurst, Douglas, 2001.

---. Siixha, Floating Overhead: The Qquuana Cycle 3.3, Translated by Robert Bringhurst, Russell Maret, 2007.

Spencer, Jasmine. "Telling animals: A histology of Dene textualized orature." 2017. U of British Columbia, PhD dissertation, doi:10.14288/1.0348713. Accessed 8 May 2020.

---. "Orality, literacy and the translator: A case study in Haida translation." Translation Studies, vol. 11, no. 3, 2018, pp. 298-314, doi:10.1080/14781700.2017.1417156. Accessed 8 May 2020.

---. "The soundscape as the transformatrice in some Dene songs and stories." Semiotica, forthcoming.

Spivak, Gayatri Chakravorty. "Can the Subaltern Speak?" Colonial Discourse and Post-Colonial Theory: A Reader, edited by Patrick Williams and Laura Chrisman, Columbia UP, 1994, pp. 66-111.

Swanton, John Reed. Haida Texts and Myths, Skidegate Dialect. Smithsonian Institution, Bureau of American Ethnology, Government Printing Office, 1905.

---. Tlingit Myths and Texts, Recorded by John R. Swanton. Smithsonian Institution, Bureau of American Ethnology, Government Printing Office, 1909. 
Tyone, Mary (Ts'ą' Yahnik). Ttheek'ädn Ut'iin Yaaniidą' Q̨onign': Old Time Stories of the Scottie Creek People. Alaska Native Language Center, 1996.

Viveiros de Castro, Eduardo Batalha. Exchanging Perspectives: The Transformation of Objects into Subjects in Amerindian Ontologies." Common Knowledge, vol. 10 , no. 3, 2004, pp. 463-84.

Vizenor, Gerald. "Aesthetics of Survivance: Literary Theory and Practice." Survivance: Narratives of Native Presence, edited by Gerald Vizenor, U of Nebraska P, 2008, pp. 1-23.

Williams, William Proctor, and Craig S. Abbott. Introduction to Bibliographical and Textual Studies. 2nd ed., MLA, 1989.

Zipes, Jack. The Brothers Grimm: From Enchanted Forests to the Modern World. 2nd ed., Palgrave, 2002. 